on-line at: www.actabp.pl

Regular paper

\title{
Cloning, sequence, expression and characterization of human $\beta$-mannosidase
}

\author{
Zahoor Qadir Samra ${ }^{\bowtie}$ and Muhammad Amin Athar \\ Institute of Biochemistry and Biotechnology, Quaid-i-Azam Campus, University of the Punjab, Lahore, Pakistan
}

Received: 12 February, 2008; revised: 20 August, 2008; accepted: 16 September, 2008

available on-line: 17 September, 2008

\begin{abstract}
$\beta$-Mannosidase (EC 3.2.1.25, MANB) dissects the non-reducing end of $\mathrm{N}$-linked mannose moieties of glycoproteins in eukaryotic cells. The human $\beta$-mannosidase gene was amplified by RTPCR, cloned and sequenced. The DNA sequence was compared with reported human $\beta$-mannosidase DNA sequence and sixteen nucleotide differences were found. The deduced amino-acid sequence showed that seven codons coded the same amino acids and nine codons coded different amino acids with reference to nucleotide substitution positions but did not affect recombinant MANB enzyme activity. No splice mutation was observed after comparison with reported MANB DNA sequences. A 75\% homology of deduced amino-acid sequence was observed with mouse, goat and bovine $\beta$-mannosidase amino-acid sequences. The cloned $\beta$-mannosidase gene was subcloned into pET22b+ and pET28a+ expression vectors to transform the BL21-codon plus cells for expression of recombinant MAN22 and MAN28 enzymes, respectively. The optimized conditions for overexpression of recombinant $\beta$-mannosidase enzyme were induction with $1 \mathrm{mM}$ IPTG for $12 \mathrm{~h}$ at $37^{\circ} \mathrm{C}$. The expressed $\beta$-mannosidase enzyme was purified to homogeneity by a combination of DEAE-ion exchange and size exclusion chromatography. The molecular mass of MAN22 and MAN28 enzymes is $97 \mathrm{kDa}$ by SDS/PAGE and is confirmed by Western blot analysis. The recombinant enzymes are active at $37^{\circ} \mathrm{C}$ and at $\mathrm{pH} 5.0$ and showed activity with $p$-nitrophenyl- $\beta$ D-mannopyranoside and not with $p$-nitrophenyl- $\alpha$-D-mannopyranoside. The $K_{\mathrm{m}}$ value of enzymes was $2.53 \mathrm{mM}$. The enzyme activity was inhibited by $\mathrm{Zn}^{2+}, \mathrm{Co}^{2+}, \mathrm{Cu}^{2+}, \mathrm{Pb}^{2+}, \mathrm{Ag}^{\mathrm{m}}$, , iodoacetate, SDS, DMF, DMSO and ethanol. $\mathrm{Fe}^{3+}, \mathrm{Ca}^{2+} \mathrm{Mg}^{2+}, \mathrm{Mn}^{2+}$, Triton X-100 and PMSF did not inhibit the enzyme activity. Northern blot analysis showed a transcript of about $3.7 \mathrm{~kb}$ in all cells and tissues studied. This is the first report on the expression and characterization of recombinant human MANB enzyme.
\end{abstract}

Keywords: $\beta$-mannosidase, cloning, sequence, expression, immunochemical reactions, Southern and Northern analysis

\section{INTRODUCTION}

Among the lysosomal hydrolytic enzymes, the $\beta$-D-mannosidase (MANB, EC 3.2.1.25) an exoglycosidase cleaves the single $\beta$-linked mannose residue from the non-reducing end of all N-linked glycoproteins ( $\beta-1-4$ GlcNac) and releases a single mannose residue (Jones et al., 1992; Percheron et al., 1992; Sopher et al., 1993; Ademark et al., 1999). This enzyme is a useful tool for structural studies of polysaccharides having $\beta$-mannosidic linkages and also for the sequencing of heteropolysaccharides and carbohydrate moieties of numerous glycoproteins. $\beta$-mannosidase activity has been characterized in many species such as fungus (Ademark et al., 1999; Kurakake \& Komaki, 2001), hyperthermophilic mi-

\footnotetext{
$\square$ Corresponding author: Zahoor Qadir Samra, Institute of Biochemistry and Biotechnology, Quaid-i-Azam Campus, University of the Punjab, Lahore, 54590, Pakistan; tel.: (92 42) 923 0134; e-mail: samra201@hotmail.com

Abbreviations: BCIP, 5-bromo-4-chloro-3-indolyl phosphate; DEAE, diethylaminoehtyl; DMF, dimethyl formamide; DMSO, dimethyl sulfoxide; DTT, dithiotheritol, ELISA, enzyme linked immunosorbant assay; IPTG, isopropyl- $\beta$-D-1-thiogalactopyranoside; MANB, $\beta$-mannosidase; $p N P-\beta$-Man, $p$-nitrophenyl- $\beta$-D-mannopyranoside; NBT, nitroblue tetrazolium; PMSF, phenylmethylsulfonyl fluoride; RT-PCR, reverse transcription-polymerase chain reaction; PAGE, polyacrylamide gel electrophoresis; SDS, sodium dodecyl sulphate; X-gal, 5-bromo-4-chloro-3-indolyl- $\beta$-D-galactopyranoside.
} 
crobes (Bauer et al., 1996; Duffaud et al., 1997) and plant (Mo \& Bewley, 2002). An inborn error of $\beta$ mannosidase activity results in $\beta$-mannosidosis in eukaryotes that leads to lysosomal storage disease in goat (Pearce et al., 1990), bovine (Sopher et al., 1993) and humans (Guadalupi et al., 1996).

$\beta$-Mannosidosis has been detected and characterized in goat (Jones et al., 1983), bovine (Jolly et al., 1990) as well as in humans. The disease is rare in humans but is globally widespread (Kleijer et al., 1990; Van et al., 1990; Alkhyat et al., 1998). The clini$\mathrm{cal} /$ pathological features of Nubain goat offspring (Render et al., 1988) and salers calves (Abbitt et al., 1991 ) with $\beta$-mannosidosis are documented as facial dysmorphism, dome shaped skulls, hyperextension of joints, muscle atrophy, marked intention tremor, inability to stand, deafness (Render et al., 1988; Bryan et al., 1990). $\beta$-Mannosidosis also results in the accumulation of oligosaccharides in fibroblasts, leukocytes, brain, kidney, liver and demyelination in the central nervous system (Van et al., 1990; Patterson et al., 1991; Lovell et al., 1994; Uchino et al., 2003).

$\beta$-Mannosidosis in humans is considered as milder clinical expression conditions with heterogeneity (Bedilu et al., 2002). Clinical studies of $\beta$-mannosidosis in humans (18 cases and thirteen families) documented mild peripheral neuropathy (Levade et al., 1994; Gort et al., 2006), hearing loss and speech impairment (Poenaru et al., 1992), epileptic encephalopathy (Cooper et al., 1991), angiokeratome (Rodriguez-Serna et al., 1996), facial dysmorphism (Kleijer et al., 1990) and reduced $\beta$-mannosidase activity in fibroblasts, plasma and leukocytes (Cooper et al., 1988). Human DNA sequence of $\beta$-mannosidase and mutations associated with $\beta$-mannosidosis have been identified (Alkhyat et al., 1996; Sedel et al., 2006).

In this paper, we report cloning, sequence, expression and characterization of $\beta$-mannosidase gene from human placenta. This is the first report about heterologous expression of human MANB enzyme. The $\beta$-mannosidase mRNA level in human tissues such as leukocytes, B and T cells was also detected. The computational analysis of deduced amino-acid sequence of cloned $\beta$-mannosidase was determined and also compared with $\beta$-mannosidase genes from other mammalian species. The MANB gene was engineered to express recombinant MANB enzyme in Escherichia coli and characterized.

\section{MATERIALS AND METHODS}

Restriction enzymes, T4 DNA ligase, recombinant Taq DNA polymerase, Biotin-11-dUTP DNA labelling kit, TA cloning kit were purchased from Fermentas Inc. Qiaquick gel extraction kit was purchased from Qiagen (USA), Bradford reagent was purchased from Biorad, $p$-nitrophenyl- $\beta$-D-mannopyranoside (pNP- $\beta$-Man), 5-bromo-4-chloro-3-indolyl phosphate (BCIP), nitroblue tetrazolium (NBT), isopropyl- $\beta$-D-1-thiogalactopyranoside (IPTG), 5-bromo-4-chloro-3-indolyl- $\beta$-D-galactopyranoside (X-gal) and all other chemicals required for routine extraction and analysis of biomolecules were purchased from Sigma. Primers were synthesized by Gene link (USA).

E. coli strains $\mathrm{DH} 5 \alpha$ (endA1, recA1, lacZ $\triangle \mathrm{M} 15$, lac $\left.{ }^{\mathrm{q}}\right)$, BL21-codon plus, BL21(DE3) and expression vectors $\mathrm{pET} 22 \mathrm{~b}(+)$, pET28a $(+)$, human $\beta$-actin DNA were gifts from Dr. Anjum Sohail, Wayne State University (USA).

Reverse transcription-polymerase chain reaction. Normal human placenta was collected from local hospital and transported to the laboratory on ice. Total RNA was extracted from placenta tissue and treated with DNase 1 as described by Sambrook and Russell (2001). RNA was reverse transcribed with M-MuLV Reverse transcriptase using Oligo(dT) ${ }_{18}$ reverse primer for synthesis of the first strand of cDNA. A set of primers [MANBF (sense) 5'-GGCCGAATTCCCATCCATgggGCGCCTCCACCTGCTCCTGCTG-3', MANBR (antisense) 5'GGGGCCCTGCAGAAGCTTTCAGTAAATATCTGTTAAGGAGGTC-3'] were designed on the basis of the open reading frame (ORF) of the human $\beta$ mannosidase sequence (Alkhyat et al., 1996, accession number U60337). NcoI and HindIII restriction sites were generated in BMANF and BMANR primers, respectively. A glycine residue (ggg) was also inserted in BMANF to complete the NcoI restriction site. PCR reaction was performed in iCycler (Biorad) using $2 \mu \mathrm{l}$ cDNA solution as template in $50 \mu \mathrm{l}$ reaction volume containing 2.5 units of recombinant Taq DNA polymerase, $1 \times$ PCR buffer, $0.2 \mathrm{mM}$ each dNTPs, $2 \mathrm{mM} \mathrm{MgCl}, 0.5 \mu \mathrm{M}$ of BMANF and BMANR primers. PCR conditions were as follows: initial denaturation for $7 \mathrm{~min}$ at $95^{\circ} \mathrm{C}$ followed by 35 cycles with denaturation at $95^{\circ} \mathrm{C}$ for $1 \mathrm{~min}$, annealing for $3 \mathrm{~min}$ at $60^{\circ} \mathrm{C}$ and elongation for $4 \mathrm{~min}$ at $72^{\circ} \mathrm{C}$ with a final elongation step of $20 \mathrm{~min}$ at $72^{\circ} \mathrm{C}$. The amplified PCR product was analyzed on $1 \%$ agarose gel using $0.5 \times$ TBE buffer. The amplified PCR product was extracted by QIAquick gel extraction kit method.

Preparation of non-radioactive biotin labelled DNA probes. For hybridization studies, biotin-11-dUTP labeled DNA probes of human $\beta$-actin DNA and amplified MANB gene were prepared as described in the labeling kit manual (Fermentas Inc.). The unincorporated biotin labeled dUTP was removed by the selective precipitation of labeled DNA with ethanol in the presence of ammonium acetate. The pellet was washed with $70 \%$ ethanol and dissolved in TE buffer. 
Cloning, characterization and sequence studies. Amplified $\beta$-mannosidase gene was ligated in pTZ57R/T vector to construct the pTA-MANB vector. Competent $\mathrm{DH} 5 \alpha$ cells were transformed with pTA-MANB vector as described in Sambrook and Russell (2001) and were spread on LB agar plates containing ampicillin $(80 \mu \mathrm{g} / \mathrm{ml})$ and X-gal/IPTG for blue/white selection. The white colonies were picked up and analyzed for $\beta$-mannosidase gene by combination of colony hybridization as described in Sambrook and Russell (2001) and detection by biotin labeled non-radioactive DNA probes (Thiel et al., 2002). The positive clones were further confirmed by colony PCR and analyzed on 1\% agarose gel using $0.5 x$ TBE buffer. The plasmid DNA was isolated by alkaline lysis with SDS method as described in Sambrook and Russell (2001) and digested with NcoI / HindIII restriction enzymes to determine the orientation of gene fragment in pTA-MANB vector. This vector is referred to as the ZEN vector.

The cloned $\beta$-mannosidase gene in ZEN vector was sequenced according to the procedure described in the Beckman coulter 8000 genetic analyzer manual. The MANB gene was primarily sequenced in the forward and reverse direction using M13 primers. The primers used for sequential sequence of MANB gene are given in Table 1. Amplification conditions include initial denaturation for $3 \mathrm{~min}$ at $97^{\circ} \mathrm{C}$ followed by 30 cycles of denaturation for $1 \mathrm{~min}$ at $95^{\circ} \mathrm{C}$, annealing for $1 \mathrm{~min}$ according to the $t_{\mathrm{m}}$ of the primers, extension for $1 \mathrm{~min}$ at $72^{\circ} \mathrm{C}$ and final extension for $20 \mathrm{~min}$ at $72^{\circ} \mathrm{C}$. The DNA sequence of the $\beta$-mannosidase gene was inserted in computer based software (webcutter version 2.0) for restriction analysis by BamHI, EcoRI and NdeI to draw the restriction map. The MANB gene was also digested with BamHI, EcoRI and NdeI restriction enzymes and analyzed on $1 \%$ agarose gel for comparison with computer based restriction analysis. The sequence of the cloned MANB gene was analyzed by blast in NCBI software to compare with the reported human $\beta$-mannosidase gene. The amino-acid sequence homology with the reported amino-acid sequence of $\beta$-mannosidase of human (U60337), bovine (U17432), mouse (Q8K214) and goat (U46067) was analysed using Clustal W programme.

Subcloning and Southern analysis of the $\beta$ mannosidase gene. The ZEN vector was digested with $\mathrm{NcoI}$ and HindIII restriction enzymes and the purified MANB gene $(2.643 \mathrm{~kb})$ was directionaly ligated into pET22b(+) and pET28a $(+)$ expression vectors as described in the pET manual (11th edn., 2006, Novagen). The resulting pET22b-MANB and pET28a-MANB plasmids were independently used to transform BL21-codon plus competent cells as described in Sambrook and Russell (2001). Positive clones of pET22b-MANB and pET28a-MANB were selected on ampicillin $(100 \mu \mathrm{g} / \mathrm{ml})$ and kanamycin $(50 \mu \mathrm{g} / \mathrm{ml})$, respectively, at $37^{\circ} \mathrm{C}$. BL21(DE3) cells were also transformed with pET22b-MANB and pET28a-MANB expression vectors under the same conditions as described above. The clones having the $\beta$-mannosidase gene were confirmed by colony PCR. The presence of the $\beta$-mannosidase gene in plasmids was further confirmed by digestion with $\mathrm{NcoI}$ and HindIII restriction enzymes and resolved on $1 \%$ agarose gel using $0.5 \times$ TBE buffer. The resolved fragments were transferred to nitrocellulose (Sambrook \& Russell, 2001) and detected by using non-radioactive biotin labeled DNA probes as decribed (Thiel et al., 2002).

Enzyme assay. $\beta$-Mannosidase activity was determined by using $p$-nitrophenyl- $\beta$-D-mannopyranoside as substrate (Uchino et al., 2003). The reaction mixture contained $300 \mu \mathrm{l}$ of $2 \mathrm{mM} p$-nitrophenyl- $\beta$ D-mannopyranoside and $20 \mu \mathrm{l}$ of extracted proteins in $0.1 \mathrm{M}$ acetate buffer, $\mathrm{pH} 5.0$, and incubated at $37^{\circ} \mathrm{C}$ for $3 \mathrm{~h}$. The reaction was stopped by adding $1.65 \mathrm{ml}$ of $0.25 \mathrm{M} \mathrm{NaOH}$. The $p$-nitrophenol released from the substrate was measured spectrophotometrically at $410 \mathrm{~nm}$. All assays were conducted in triplicate. The unit of enzyme is defined as the amount of enzyme that releases $1.0 \mu \mathrm{mol}$ of $p$-nitrophenol per minute under the assay condition.

Induction and expression of the recombinant MANB enzyme. The transformed cells of BL21-codon plus and BL21(DE3) were grown at $37^{\circ} \mathrm{C}$ in $\mathrm{LB}$ medium containing antibiotics as described above. When the $\mathrm{OD}_{600}$ reached $0.5-0.6,1 \mathrm{ml}$ sample from each culture was removed as control. To the remaining culture, isopropyl $\beta$-D-thiogalactoside $(0.2,0.4$, $0.6,0.8$ and $1.0 \mathrm{mM}$ ) was added independently in each culture. One milliliter of each induced culture was taken at 2-h intervals up to $14 \mathrm{~h}$ at each temperature $\left(16,20,25,30,37\right.$ and $\left.40^{\circ} \mathrm{C}\right)$. Expression of recombinant MANB enzymes was determined by 10\% SDS/PAGE (Laemmli, 1970) and enzyme assay (Uchino et al., 2003).

The transformants of BL21-codon plus containing pET22b-MANB and pET28a-MANB plasmids were designated as SA22 and SA28, respectively. The transformants SA22 and SA28 were grown overnight separately in $10 \mathrm{ml}$ LB medium and $1 \%$ volume of overnight culture was used to inoculate $500 \mathrm{ml}$ fresh LB medium containing ampicillin $(100 \mu \mathrm{g} / \mathrm{ml})$ and kanamycin $(50 \mu \mathrm{g} / \mathrm{ml})$ separately at $37^{\circ} \mathrm{C}$. The cells were induced with $1 \mathrm{mM}$ IPTG when $\mathrm{OD}_{600}$ was between 0.5 and 0.6. The cells were harvested after $12 \mathrm{~h}$ induction at $37^{\circ} \mathrm{C}$. The induced cells were mixed with $2 \times$ SDS/PAGE sample buffer and electrophoresed on 10\% SDS/PAGE (Laemmli, 1970). Gels were stained with Coomassie Brilliant Blue R-250 and destained. The presence of recombinant $\beta$-mannosidase enzyme was analyzed in growth culture 
medium, periplasmic and cytoplasmic fractions of clones SA22 and SA28 by enzyme linked immunosorbant assay (Samra \& Athar, 2008) and MANB enzyme assay (Uchino et al, 2003). The expressed protein was mainly detected in the periplasmic fraction.

\section{Purification of MANB enzyme}

Cell lysis and precipitation of proteins. The recombinant $\beta$-mannosidase enzyme was extracted from IPTG induced cells. The cells were harvested at 5000 r.p.m. at $4^{\circ} \mathrm{C}$, resuspended in $10 \mathrm{ml}$ of osmotic shock buffer A $(0.05 \mathrm{M}$ acetate buffer, $\mathrm{pH} 5.0$ including protease inhibitors with final concentration of $10 \mu \mathrm{g} / \mathrm{ml}$ aprotinin, $10 \mu \mathrm{g} / \mathrm{ml}$ leupeptin, $1 \mathrm{mM}$ EDTA, $1 \mathrm{mM}$ PMSF, $1 \mathrm{mM}$ DTT, 20\% sucrose) and stored on ice for $20 \mathrm{~min}$. The cells were centrifuged again at 5000 r.p.m. for $5 \mathrm{~min}$ at $4^{\circ} \mathrm{C}$ and resuspended in $10 \mathrm{ml}$ osmotic shock buffer A without $20 \%$ sucrose and incubated on ice for 10 to $15 \mathrm{~min}$. Lysed cells were centrifuged at 10000 r.p.m. for $5 \mathrm{~min}$ at $4^{\circ} \mathrm{C}$. Supernatant was collected and ammonium sulphate was added to $30 \%$ saturation and stored in ice for $6 \mathrm{~h}$. The mixture was centrifuged at 10000 r.p.m. for $15 \mathrm{~min}$ at $4^{\circ} \mathrm{C}$. Supernatant was collected and ammonium sulphate was added to $60 \%$ saturation. After centrifugation, supernatant was aspirated and the pellet was dissolved in $5 \mathrm{ml}$ of mannosidase buffer (0.05 M acetate buffer, $\mathrm{pH} 5.0)$ and dialyzed against 21 of mannosidase buffer. The protein concentration was estimated by Bradford dye binding reagent using bovine serum albumin as standard (Bradford, 1976).

DEAE-cellulose chromatography. The dialyzed protein fraction was loaded on DEAE-cellulose $(1.5 \mathrm{~cm} \times 20 \mathrm{~cm})$ equilibrated with mannosidase buffer. The column was washed with two column volume of the same buffer. The adsorbed proteins were eluted with a linear gradient of $\mathrm{NaCl}(0$ to $0.5 \mathrm{M}$ ) in the mannosidase buffer at a flow rate of $1 \mathrm{ml} / \mathrm{min}$. One milliliter fractions were collected. The fractions containing $\beta$-mannosidase enzyme activity were pooled, dialyzed against 21 of mannosidase buffer for $3 \mathrm{~h}$ and finally concentrated to $5 \mathrm{ml}$ volume using amicon ultrafiltration cell with $30 \mathrm{kDa}$ cut off membrane under nitrogen positive pressure at 55 psi. The protein concentration was estimated by the Bradford (1976) dye binding method.

Size exclusion chromatography. The protein fractions pooled from ion exchange column were subjected to size exclusion chromatography on Sephadex G-200 $(1.5 \mathrm{~cm} \times 30 \mathrm{~cm})$ equilibrated with mannosidase buffer (0.05 $\mathrm{M}$ acetate buffer, $\mathrm{pH}$ 5.0). Two milliliter fractions were collected at flow rate of $0.5 \mathrm{ml} / \mathrm{min}$. The fractions containing $\beta$-mannosidase activity were pooled and concentrated in Amicon ultrafiltration cell as described above. The con- centrated protein was analyzed by 10\% SDS/PAGE and ELISA. After purification and characterization, the concentration of recombinant $\beta$-mannosidase enzyme was estimated by the Bradford (1976) dye binding method.

\section{Characterization of MANB enzyme}

Western bloting. The induced proteins were separated on $10 \%$ SDS/PAGE and electrophoretically transferred onto nitrocellulose membrane (Towbin et al., 1979). The immunochemical reaction was carried out with mouse anti-human $\beta$-mannosidase antibodies and alkaline phosphatase (AP)-conjugated rabbit anti-mouse IgG antibody as described (Samra \& Athar, 2008). The colour reaction was developed using nitroblue tetrazolium and 5-bromo-4-chloro3-indolylphosphate as substrates (Harlow \& Lane, 1988).

Effect of $\mathrm{pH}$ and temperature. The effect of $\mathrm{pH}$ and temperature on $\beta$-mannosidase activity was determined using pNP-Man as substrate. The MANB enzyme activity of purified enzyme was checked at different $\mathrm{pH}$ values $(3.0,4.0,5.0,6.0,7.0,8.0$ ) of mannosidase buffer at $37^{\circ} \mathrm{C}$. The effect of temperature was checked by incubating the enzyme in mannosidase buffer at $\mathrm{pH} 5.0$ at various temperatures $\left(20,25,30,37,40,50^{\circ} \mathrm{C}\right)$ for $30 \mathrm{~min}$ and the relative activity was measured under standard assay conditions as described above. The thermostability of the enzyme was also checked up to $4 \mathrm{~h}$ under standard assay conditions. All assays were conducted in triplicate.

Effect of metal ions and organic reagents. The effect of metal ions, such as $\mathrm{Mg}^{2+}, \mathrm{Mn}^{2+}, \mathrm{Zn}^{2+}, \mathrm{Ca}^{2+}$, $\mathrm{Fe}^{3+}, \mathrm{Co}^{2+}, \mathrm{Cu}^{2+}, \mathrm{Pb}^{2+}, \mathrm{Ag}^{1+}$ was investigated with $1.5 \mathrm{mM}$ final concentration in the reaction mixture. The effect of other reagents such as iodoacetate, SDS, DMF, DMSO and ethanol was estimated with $5 \mathrm{mM}$ concentration. The purified MANB enzyme was preincubated with the above described compounds for $15 \mathrm{~min}$ at $37^{\circ} \mathrm{C}$ and the activity was measured under the standard assay conditions. The activity without metal ions and reagents was considered as $100 \%$.

Kinetic study. The kinetic parameter was determined using pNP-Man as substrate. The liberated $p$-nitrophenol was measured using different concentrations of substrate ( 1 to $5 \mathrm{mM}$ ). All assays were conducted in triplicate. Values for Michaelis-Menton constant $\left(K_{\mathrm{m}}\right)$ were determined from LineweaverBurk plot method (Plumer, 1987).

Analysis of $\beta$-mannosidase RNA in human cells and tissue. The peripheral blood leukocytes were isolated from heparinized blood on Histopaque-Ficoll density gradient as described (Johnstone \& Thrope, 1982). B- and T-lymphocytes were extracted by the panning method using mono- 
clonal antibodies against anti-CD21 and anti-CD4/ anti-CD8 for B and T cell receptors, respectively, as described by Wysocki and Sato (1978), Samra and Athar (2008). Total RNA from human placenta, leukocytes, B and T lymphocytes was extracted as described by Sambrook and Russell (2001) and the $\operatorname{Poly}(\mathrm{A})^{+}$RNA was separated from total RNA using oligo-dT cellulose resin as described by Ausubel et al. (2002). Two micrograms Poly(A) ${ }^{+}$ RNA of each specimen was resolved on $1 \%$ formaldehyde agarose gel and transferred onto nitrocellulose membrane as described by Sambrook and Russell (2001). The transferred poly $(\mathrm{A})^{+}$RNA was detected by using biotin labeled DNA probes as described (Thiel et al., 2002). After removal of MANB probes, the blot was rehybridized with biotin labeled $\beta$-actin probes as control and detected as described above.

Accession number. The described $\beta$-mannosidase gene amplified by RT-PCR from human placenta was submitted to GenBank and the alloted accession No. is EU009130.

\section{RESULTS}

\section{Cloning and sequence analysis}

Total RNA was isolated from human placenta to fish out the $\beta$-mannosidase gene for cloning and expression. The oligo-dT primed cDNA libraries were utilized to amplify the $\beta$-mannosidase gene by using primers of the ORF region. The size of the PCR product was $2.643 \mathrm{~kb}$ and it was ligated in $\mathrm{pTZ} 57 \mathrm{R} / \mathrm{T}$ vector to construct the pTA-MANB hybrid vector (ZEN vector) for sequencing studies. Colony PCR and the restriction digestion with $\mathrm{NcoI}$ and HindIII enzymes confirmed the presence of $2643 \mathrm{~kb}$ gene. The ZEN vector containing the $\beta$ mannosidase gene was subjected to DNA sequence analysis. The DNA sequence was analyzed by Blast for comparison of the cloned $\beta$-mannosidase gene which indicated $99 \%$ homology with the reported human $\beta$-mannosidase sequence (Alkhyat et al., 1998). Sixteen nucleotide differences were found in the sequences of the $\beta$-mannosidase gene (Fig. 1). The evaluation of triplet codon for amino acids at the position of nucleotide difference indicated that five amino acids remain the same at nucleotide positions 486, 489, 757, 1011, 1137 and eleven showed different amino-acids at nucleotide positions 208, 390, 479, 862, 889, 1037, 1039, 1130, 1137, 1598, 1766, 2590. On alignment of the deduced amino acid sequence of this $\beta$-mannosidase with the reported amino-acid sequence of human $\beta$-mannosidase, nine amino acid differences is found which are highlighted at positions 253, 288, 297, 346, 347, 377, 533, 589, 864 (Fig. 2). This enzyme shows 75\% homology with mouse, goat and bovine $\beta$-mannosidase (Fig. 2). The comparison of computer base restriction analysis of MANB gene with BamHI, EcoRI and NdeI restriction enzymes with restriction digestion and analysis on agarose gel indicated the same fragments (Fig. 3). BamHI releases two fragments of 1570 and $1073 \mathrm{bp}, E c o$ RI releases three fragments of $1198,738,707 \mathrm{bp}$ and NdeI releases two fragments of 1353 and $1290 \mathrm{bp}$.

\section{Subcloning and expression of MANB enzymes}

The E. coli strains BL21-codon plus and BL21(DE3) cells were transformed independently with pET22b-MANB and pET28a-MANB hybrid expression vectors for expression the MANB enzyme. The restriction digestion of these vectors with NcoI/ HindIII restriction enzymes, colony PCR and Southern analysis confirmed the presence and orientation of the $2643 \mathrm{~kb}$ MANB gene. The recombinant $\beta$-mannosidase enzyme was expressed in BL21-codon plus whereas expression was not

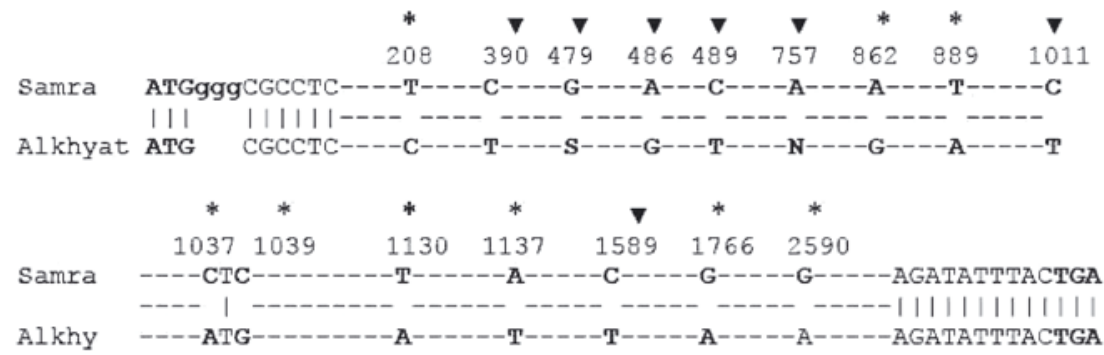

Figure 1. Alignment and comparison of DNA sequence of cloned $\beta$-mannosidase (EU009130) with reported human $\beta$ mannosidase (U60337).

The difference of nucleotide sequence at sixteen positions is shown $\left(^{*}\right)$ excluding the ggg codon in DNA comparison. ATG indicates start codon whereas TGA shows stop codon. The ggg codon was inserted to create the NcoI restriction site. Dashes and vertical bars indicate the same nucleotide sequence. Arrow head ( $\boldsymbol{\nabla})$ indicates the difference of triplet codon but the amino acid is same in both MANB sequences. Asterik $\left(^{*}\right)$ indicates the difference of nucleotides as well as the amino acids. 
SMANB MRLHLLLLIALCGAGTTAAELSYSLRGNWSICNGNGSLELPGAVPGCVHSALFOQGLIQDSYYRFNDLNY AMANB MRLHLLLLLALCGAGTTAAELSYSLRGNWSICNGNGSLELPGAVPGCVHSALFOQGLIODSYYRFNDLNY MOUSE MHLHLLLILALFRAGCVVAGPSYSLSGSWRVSNGNGSLELPATVPGYVHSALHQHGLIODPYYRFNDLNY BOVINE MLLRLLLLIAPCGAGFATKVVSISLRGNWKIHSGNGSLQLPATVPGCVHSALFNRRIIKDPYYRFNNLDY GOAT MLLRLLLLLAPCGAGFATEVVSISLRGNWRIHNGNGSLQLPAAVPGCVHSALFNRRI IRDPYYRFNNLDY

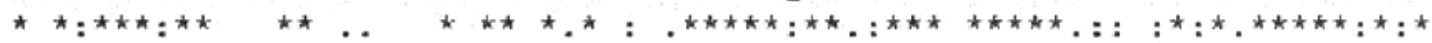
71 V 140

SMANB RWVSLDNWTYSKEFRIPFE ISKWQKVNLILEGVDTVSKILFNEVT I GETDNMFNRYSFDITNVVRDVNSI AMANB RWVSLDNWTYSKEFRIPFE ISKWOKVNLI LEGVDTVSK I LFNEVT I GET DNMFNRYSFDITNVVRDVNSI MOUSE RWISLDNWTYSTEFRIPFNLSEWQKVRLIFDGVDTVAEILFNNVT IGKTDNMFTGYSFDITNVVKDVNSL BOVINE RWIALDNWTYIKRFRLHSDMSTWSKVNLVFEGIDTVAVYLINSVPIGKTDNMFRRYSFDITHTVKAVNII GOAT RWIALDNWTYIKRFRLHSDMSEWNKVNLVFEGIDTVAVVLINSVPIGKTDNMFRRYSFDITHMVKAVNII

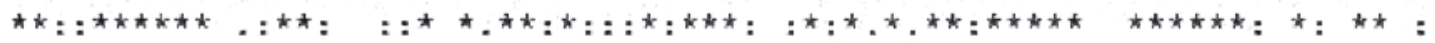
141

SMANB ELRFQSAVLYAAQQSKAHTRYQVPPDCPPLVQKGECHVNFVRKEQCSFSWDWGPSFPTQGIWKDVRIEAY AMANB ELRFQSAVLYAAQQSKAHTRYQVPPDCPPLVQKGECHVNEYRKEQCSFSWDWGPSFPTQGIWKDVRIEAY MOUSE KLQFRSAVQYAECQSKAHTSYRVP PECP PVEQKGECHVNFIRKAQCSESWDWGPSFPSQGIWKDVRIEAY BOVINE EVRFQSPVVYANQRSERHTAYWVP PNCP PPVQDGECHVNFIRKMQCSEGWDWGPSFPTQGIWKDVRIEAY GOAT EVRFQSPVIYANQRSERHTAYWVPPNCPPPVQDGECHVNFIRKMQCSEGWDWGPSFPTQGIWKDVRIEAY

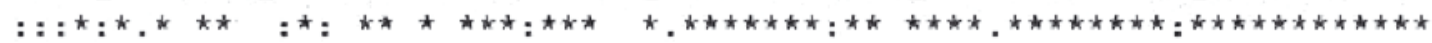
211 280V

SMANB NICHLNYFTFSPIYDKSAQEWNLEIESTFDVVSSKPVGGQVI IAIPRLQTQQTYSIELQPGRRIVELFVN AMANB NICHLNYFTFSPIYDKSAQEWNLEIESTFDVVSSKPVGGQVIVAIPKLQTQQTYS IELQPGKRIVEIFVN MOUSE NIAHLDYLTFLPVYDNASQAWNIEIKASFDVASSKSVGGQVTVAIPQLKTQQTNDIELQQEQRIVKLLVR BOVINE NVCHLNYFMFTPIYDNYMKTWNLKIESSFDVVSSRLVSGEAIVAIPELNIQOTNNIELQHGERTVELFVR GOAT NICHLNYFMFTPIYDNYMETWNLKIESSFDVVSSRLVSGEAIVAIPELNIQQRNNIELRHGERTVRLFVR

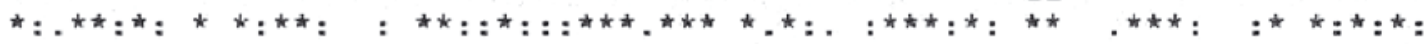
281 V SMANB ISKNITVKTWWPHGHGIQTGYNMTVLFELDGGLNIEKSAKVYFRTVELIEEPIKGSPGLSFYFRITRFPI AMANB ISKNITVETWWPHGHGNOTGYNMTVLFELDGGLNIERSARVYFRTVELIEEPIRGSPGLSFYFRINGFPI MOUSE IRKDVAVETWWPRGHGNQTGYNMTILFALDGGLRIERAARVYFRTVQLIEEGIKGSPGLSFYFKINGLPI BOVINE IDKAI IVETWWPHGHGNQTGYNMSVIFELDGGLRFERSARVYFRTVELVEEPIQNSPGLSFYFKINGLPI GOAT IDKAVIVETWWPHGHGNQTGYDMTVTFELDGGLRFERSARVYFRTVELVEEPIQNSPGLTFYFKINGLPI

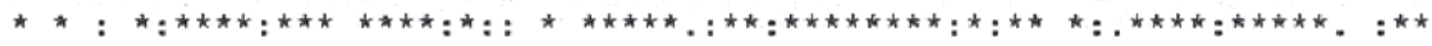
3512420

SMANB FLRGSNWIPADSFQDRVTSELLRLLLLSVVDANMNTLRVWGGGIYEQDEFYELCDELGIMVWQDFMFACA AMANB FLKGSNWIPADSFQDRVT SELLRLLIQSVVDANMNTLRVWGGGIYEQDEFYELCDELGIMVWQDFMFACA MOUSE FLKGSNWIPADSFQDKVTSDRLQLLFQSVVDANMNTLRVWGGGIYEQDEFYALCDELGIMVWQDFMFASA BOVINE FLKGSNWIPADSFQDRVT SAMLRLLIQSVVDANMNALRVWGGGVYEQDEFYELCDEIGIMIWQDFMFACA GOAT FLKGSNWIPADSFQDRVTSDMLRLLIQSVVDANMNALRVWGGGIYEODEFYELCDELGIMIWQDFMFACA

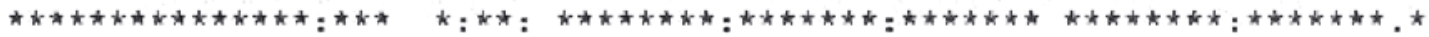
421 490

SMANB LYPTDQGFLDSVTAEVAYQIRRLKSHPSI I IWSGNNENEEALMMNWYHISFTDRPIYIKDYVTLYVKNIR AMANB LYPTDQGFLDSVTAEVAYQIRRLKSHPSI I IWS GNNENEEALMMNWYHISFTDRPIYIKDYVTLYVKNIR MOUSE LYPTEPGFLASVRKEVTYQVRRLRSHPSI I IWS GNNENEVALSVNWF HVNPRDMRTYIDDYVTLYVKNIR BOVINE LYPTDRDFMDSVREEVTHQVRRLRSHPSIITWSGNNENEAALMMGWYDTRPGYLQTYIRDYVTLYVRNIR GOAT LYPTDEDFMDSVREEVTHQVRRLRSHPSI ITWSGNNENEAALMMGWYDTKPGYLHTYIRDYVTLYVKNIR

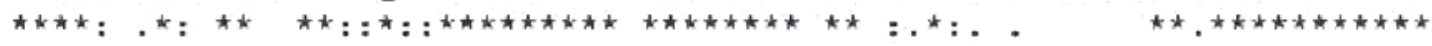
491

SMANB ELVLAGDRSRPFITSSPTNGAETVAEAWVSQNPNSNYFGDVHLYDYISDCWNWKVFPKARFASEYGYQSW AMANB ELVLAGDKSRPFITSSPTNGAETVAEAWVSONPNSNYEGDVHFYDYISDCWNWKVFPKARFASEYGYQSW MOUSE KIVLSEDRSRPFIASSPTNGMK TMEEGWISYDPYS IQYGDI HFYNYADCWNWKI FPRARLVSEYGYQSW BOVINE TIVLEGDQTRPFITSSPTNGAKTIAEGWLSPNPYDLNYGDVHFYDYVSDCWNWRTFPKARFVSEYGYQSW GOAT TIVLEGDQTRPFIISSPTNGAKTTAEGWLSPNPYDLNYGDVHFYDYMSDCWNWRTFPKARFVSEYGYQSW

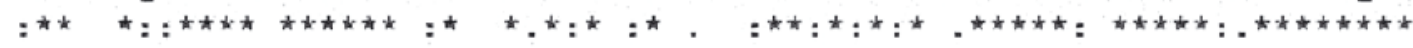




\begin{tabular}{|c|c|}
\hline & 61 \\
\hline NB & EVVSTEDWS FNSKFSLHRQHHGGGNRQMLYQAGLHERLPQSTDPLRTFRDTIYLTQVMOAQ \\
\hline MANB & STLEKVSSTEDWS FNSRFSLHRQHHEGGNRQMLYQAGLHFRLPQSTDPLRTFRDTIYL \\
\hline OUSE & STLEKVSSQEDWAYNSRFSLHRQHHEDGNHQMLHQVKMHFRLPQGTDPLRTFRDTIYLTQVMO \\
\hline BOVINE & FSTLEKVSSEEDWSYRSSFALHRQHLINGNNEMUHQIELHFRLPNSTDQLRRFRDTLYLT \\
\hline \multirow[t]{3}{*}{ GOAT } & SFSTLEKVSSEEDWSYESSFALHRQHLINGNSEMLQQIELHFRLPNSADQLRRFRDTLYLTQVMOAQ \\
\hline & 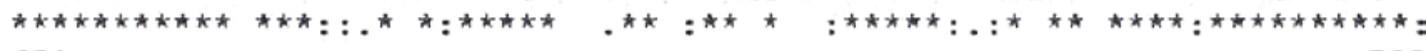 \\
\hline & 631 \\
\hline MANB & KTETEFYRRSRSEIVDQQGHTMGALYWQLNDIWQAPSWASLEYGGKWKMLHYFAQNFFAPLIPVGEEI \\
\hline MANB & TETEFYRRSRSEIVDQQGHTMGALYWQLNDIWQAPSWASLEYGGKWKMLHYFAQNFFAPLLPVGEENEN \\
\hline OUSE & KTETEFYIRSRSEIVDGKGHTMGALYWQLNDIWQAPSWASLEYGGKWKMLHYFARRFFAPLLPVGEED \\
\hline BOVINE & KTETEFYRRSRSEIVNGKGHTMGALYWQLNDIWQAPSWSSIEYGGKWKMLHYFARHFEAPLIPVGEEDKI \\
\hline \multirow[t]{2}{*}{ GOAT } & 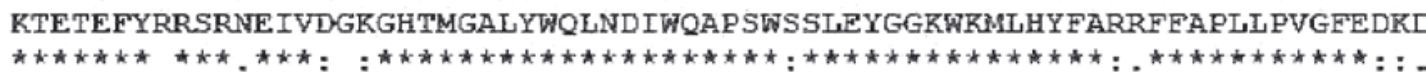 \\
\hline & 701 \\
\hline NB & IHSDYSMTLSVRVHTWSSLEPYCSRVTERFVARGGEAVCLYEEPVSELLRRCGNCTRES \\
\hline AMANB & TFYIYGVSDIHSDYSMTLSVRVHTWSSLEPVCSRVTERFVMRGGEAVCLYEEPVSELLRRCGNCTRES \\
\hline COUSE & VFYVYGVSDIHKDHHTQLTVRLHHWSSPKPLCSLVNSSIVVKAGEAVVLFEMPVSELLKRCRGCTRE' \\
\hline BOVINE & MLFIYGASHLHSDQOMULTVVHTWSSLELVCSESTNPFVI KAGESVLLYTKPVPELLRGCPGCTRQS \\
\hline \multirow[t]{2}{*}{ GOAT } & VLFIYGVSDLPSDHOMMLTVVHTWSSLELVCSELTNPFVMRÄGESVVLYSKPVPELLRGCPGCTRQSCV \\
\hline & 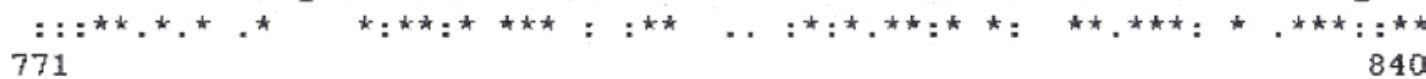 \\
\hline SMANB & VSFYLSADHELLSPTNYHFLSSPKEAVGLCKAQITAI I SQQGDIFVFDLETSAVAPFVWLDVGSIPGI \\
\hline AMANB & VSFYLSADHELLSPTNYHFLSSPKEAVGLCKAQITAI I SQQGDI FVFDLETSAVAPFVWLDVGSIPG \\
\hline SOUSE & VSFYFSTDKELFSPTNYHFLSSLRDARGLLEANITVNI SQRGNVFVFDLETSAVAPFVWLDVGSIPGI \\
\hline BOVINE & VSFYLSTDGELLSPINYHFISSLKNARGLHKANITATISQQGDTFVFDLKTSAVAPFVWLDVGSIPGI \\
\hline \multirow[t]{2}{*}{ GOAT } & ELSTDGELLSPINYHFLSSLKNARGLHKANITATISQQGNTFVFDLKTSAVAPFVWLDVGSIPG \\
\hline & 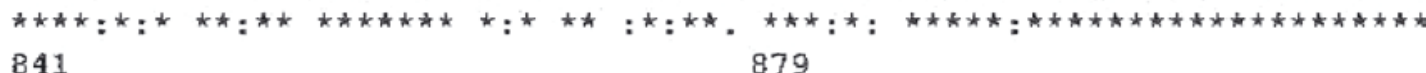 \\
\hline
\end{tabular}

SMANB DNGFLMTEKTRTILFYPWEPTSKDELEQSFHVTSLTDIY

AMANB DNGFLMTEKTRTILFYPWEPTSKNELEQSFHVTSLTDIY

MOUSE DNGFLMIRRKLSVLFYPWRPTSKSELQQAFSVTSLTDTY

BOVINE DNGFLMTEKTRTVFFYPWRPTSKSELEQSFHVTSLADTY

GOAT DNGFLMTEKTRTVFFYPWKPTSKSELEQSFHVTSLADTY

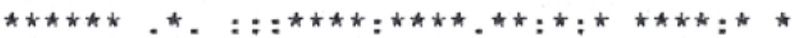

Figure 2. Alignment and comparison of amino-acid sequences of $\beta$-mannosidase genes.

SMANB stands for cloned human $\beta$-mannosidase in this study (EU009130) and AMANB stands for reported Alkhayat et al. (1998) $\beta$-mannosidase (U60337). Alignment of amino-acid sequences of SMANB with other reported mammalian $\beta$ mannosidases, AMANB (U60337), goat (U46067), bovine (U17432), mouse (Q8K214t). Sequences were aligned using Clustal W programme (1.83) multiple sequence alignment software. $\left(^{*}\right)$ The conserved aligned amino-acid sequence is shown by asterisks, (.) indicates conserved substitution and (:) indicates semiconserved substitution. The bold letters indicate the amino acid differences in human $\beta$-mannosidases. Arrow head $(\boldsymbol{\nabla})$ indicates the glycosylation sites as reported in U60337. One glycosylation difference is found at position 297, where $\mathbf{N}$ is changed to an I residue.

observed in BL21(DE3) after induction with IPTG. Two transformants of BL21-codon plus carrying pET22b-MANB and pET28a-MANB expression vectors were designated as SA22 and SA28, respectively. Maximum expression of recombinant enzyme was observed after induction with $1 \mathrm{mM}$ IPTG for $12 \mathrm{~h}$ at $37^{\circ} \mathrm{C}$ (Fig. $4 \mathrm{~A}$ ). The $\beta$-mannosidase activity was measured in crude bacterial extract which showed that the enzyme is in the active form. The expression of recombinant MANB enzyme was checked by ELISA and Western blot analysis using anti-human $\beta$-mannosidase antibodies. The expected $97 \mathrm{kDa}$ recombinant protein was visualized in Western blot analysis (Fig. 4B).

\section{Purification of recombinant MANB enzyme}

Distribution of the expressed protein was checked in cytosolic, periplasmic and culture medium fractions by enzyme assay. The MANB enzyme activity was identified in periplasmic fractions of clones SA22 and SA28 and these were named as MAN22 and MAN28 enzyme, respectively. The enzyme showed $75-80 \%$ activity after purification by combination of chromatography techniques. The elution profile of the enzyme in ion exchange and size exclusion chromatography is shown (Fig. 5A and 5B, respectively). Recombinant MANB enzyme from SA22 and SA28 was purified 112 to 126 fold with a yield of nearly $78 \%$ 
Table 1. Oligonucleotide primers used for sequencing of $\beta$-mannosidase gene

\begin{tabular}{lll}
\hline $\begin{array}{l}\text { Primer } \\
\text { name }\end{array}$ & $\begin{array}{l}\text { bp po- } \\
\text { sition }\end{array}$ & Sequences $\left(5^{\prime} \rightarrow 3^{\prime}\right)$ \\
\hline Fo sense & - & M13 sequence forward primer \\
F1 sense & 570 & GGGTGAATGCCATGTCAACT \\
F2 sense & 1090 & AGGACCGAGTAACCTCTGAG \\
F3 sense & 1665 & GGATATCAGTCCTGGCCGTC \\
F4 sense & 2235 & GGCTGTCTGCCTTTATGAGG \\
Ro antisense & - & M13 sequence reverse primer \\
R1 antiense & 2266 & TATCTATTGAACATATTGTC \\
R2 antiense & 1769 & GGCCACC AAGTTTCTACAGT \\
R3 antiense & 1272 & CATTTTCATTATTGCCACTG \\
R4 antiense & 776 & TGAGTAAGGTAGATGGTATC \\
R5 antiense & 234 & CGCCTTGCAGAGCCCCACGG \\
\hline
\end{tabular}

bp, base pair; F, Forward; R, Reverse

and has specific activity of 9.45 to $12.66 \mathrm{U} / \mathrm{mg}$, respectively (Table 2). The purified protein was analyzed by $10 \%$ SDS/PAGE and was detected as a $97 \mathrm{KDa}$ protein band in Western blot analysis (Fig. 4C).

\section{Biochemical properties}

The optimal enzyme activity of MAN22 and MAN28 was observed at $37^{\circ} \mathrm{C}$ at $\mathrm{pH} 5.0$ (Fig. 6A). The enzyme activity was reduced at $\mathrm{pH} 6.0$ and 7 and totally inactivated at higher alkaline $\mathrm{pH}$. A complete loss of activity was observed at $50^{\circ} \mathrm{C}$ therefore the enzyme is unstable at $50^{\circ} \mathrm{C}$ (Fig. 6B). The thermostability of the enzyme was studied for a period of $6 \mathrm{~h}$. The activity was completely lost after $4 \mathrm{~h}$. The $K_{\mathrm{m}}$ value of MAN22 and MAN28 enzyme is $2.53 \mathrm{mM}$ with $p$-nitrophenyl- $\beta$-D-mannopyranoside. Metal ions such as $\mathrm{Fe}^{+3}, \mathrm{Ca}^{+2}, \mathrm{Mg}^{+2}$, $\mathrm{Mn}^{+2}$ did not show any inhibitory or stimulatory effect whereas $\mathrm{Pb}^{2+}$ and $\mathrm{Co}^{2+}$ showed moderate inhibitory effect while $\mathrm{Zn}^{2+}, \mathrm{Cu}^{2+}, \mathrm{Ag}^{1+}$ ions inhibited the enzyme activity. Organic compounds such as Triton X-100, PMSF did not show any effect on the enzyme activity, whereas, idoacetic acid, SDS, ethanol, DMF, DMSO completely destroyed the $\beta$ mannosidase activity (Table 3).

Table2. Purification scheme of recombinant human $\beta$-mannosidase enzyme

A. For recombinant MAN28 enzyme

\begin{tabular}{llllll}
\hline Fractions & Total protein & Total activity & Specific activity & Purification & Yield \\
\cline { 2 - 6 } & $(\mathrm{mg})$ & $(\mathrm{U})$ & $(\mathrm{U} / \mathrm{mg})$ & fold & $(\%)$ \\
\hline 1. Periplasm fraction & 928 & 98 & 0.105 & 1 & 100 \\
2. DEAE-Cellulose & 33 & 89 & 2.69 & 26.9 & 90 \\
3. Gel filtration (G-200) chromatography & 6 & 76 & 12.66 & 126.6 & 77 \\
\hline
\end{tabular}

B. For recombinant MAN22 enzyme

\begin{tabular}{|c|c|c|c|c|c|}
\hline \multirow[t]{2}{*}{ Fractions } & Total protein & Total activity & Specific activity & Purification & Yield \\
\hline & $(\mathrm{mg})$ & $(\mathrm{U})$ & (U/mg) & fold & $(\%)$ \\
\hline 1. Periplasm fraction & 1045 & 88 & 0.084 & 1 & 100 \\
\hline 2. DEAE-Cellulose & 40 & 78 & 1.95 & 23.21 & 93 \\
\hline 3. Gel filtration (G-200) chromatography & 7.3 & 69 & 9.45 & 112.5 & 78 \\
\hline
\end{tabular}

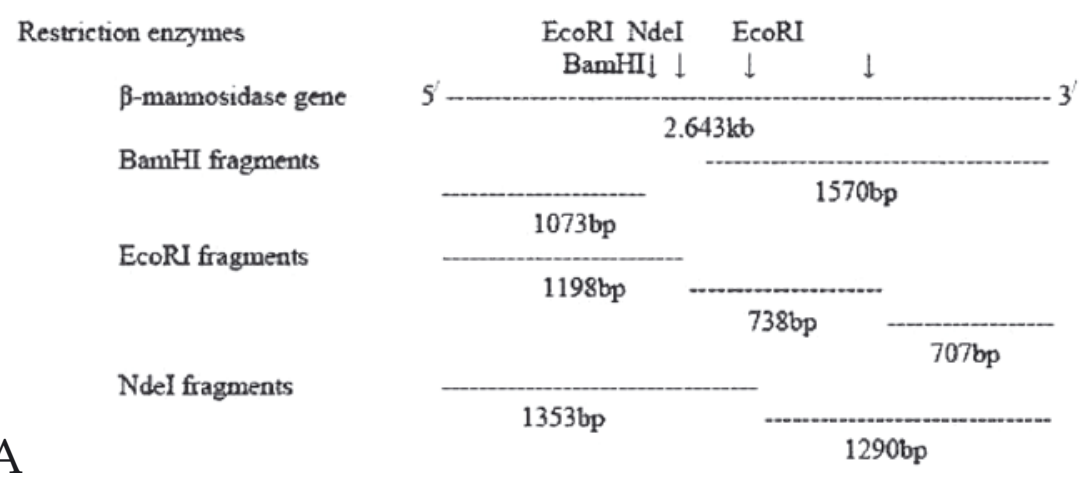

Figure 3. Representation of the restriction digestion of the $\beta$-mannosidase gene.

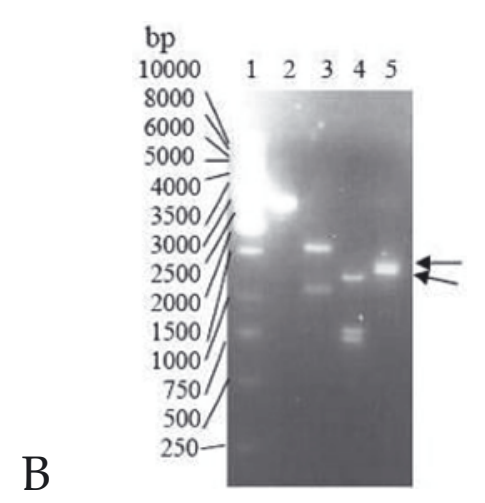

(A) The DNA sequence of $\beta$-mannosidase gene was inserted in web cutter software programme and digested with BamHI, EcoRI and NdeI restriction enzymes. (B) The $\beta$-mannosidase gene fragment was digested with BamHI, EcoRI and NdeI and analyzed on $1 \%$ agarose gel. Lane 1, DNA ladder $1 \mathrm{kbp}$; Lane 2, purified PCR fragment of $\beta$-mannosidase gene; Lane 3, BamHI releases two fragments of 1570 and 1073 bp; Lane 4, EcoRI releases three fragments of 1198, 738, 707 bp; Lane 5, NdeI releases two fragments of 1353 and 1290 bp (arrow). 


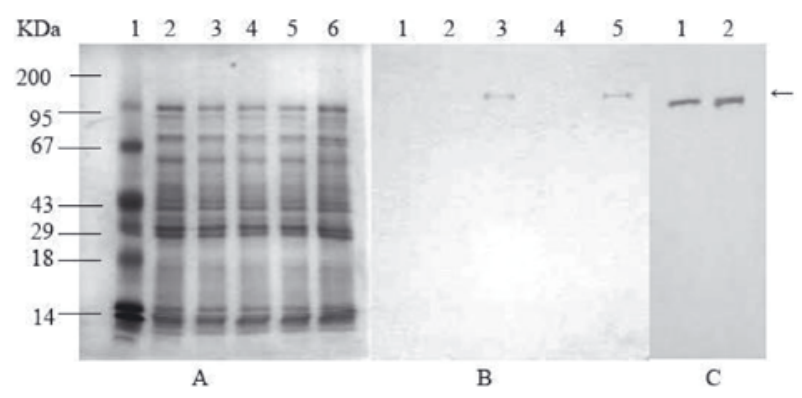

Figure 4. SDS/PAGE and Western blot analysis of MANB22 and MANB28 proteins.

(A) SDS/PAGE. Lane 1, standard molecular mass protein marker; Lane 2, Lysate of BL21-codon plus; Lane 3, Lysate of BL21-codon plus containing pET28a vector; Lane 4, Lysate of BL21-codon plus containing pET22b-MANB vector; Lane 5, Lysate of BL21-codon plus containing pET22b vector; Lane 6, Lysate of BL21-codon plus containing pET28a-MANB vector. Cells in lanes 3 to 6 were induced with $1 \mathrm{mM}$ IPTG for $12 \mathrm{~h}$. (B) Western blot analysis. Proteins from the gel shown in Fig. 3B were transferred onto a nitrocellulose membrane and immunostained with mouse anti-human $\beta$-mannosidase antibodies. $\beta$-Mannosidase expressed MANB22 and MANB28 proteins bands $(97 \mathrm{kDa})$ are shown in lane 3 and 5 respectively. (C) Western blot analysis of purified recombinant. MANB22 (lane1), MANB28 (lane 2) proteins. The arrow at the right side of the blot indicates the purified enzymes.

\section{Northern analysis}

A Northern analysis of mRNA isolated from placental, leukocytes, B and T cells showed a $3.7 \mathrm{~kb}$ transcript. The level of expression of transcript was relatively high in placental tissue in comparison to B and $\mathrm{T}$ cells (Fig. 7).

\section{DISCUSSION}

Among eukaryotic hydrolases, $\beta$-mannosidase is an important enzyme which dissects the non-reducing end of the $\beta$-linked mannose residue $(\beta-1-4$ GlcNac) in the degradation pathway of glycoproteins and complex oligosaccharide (Ademark et al., 1999; Bauer et al., 1996; Duffaud et al., 1997; Kurakake \& Komak, 2001). When $\beta$-mannosidase enzyme fails to hydrolyze $\beta$-mannose from glycoproteins, undegraded oligosaccharide appears in urine and is stored in tissues. The accumulation of oligosaccharide can cause a lysosomal storage disease called $\beta$-mannosidosis (Pearce et al., 1990; Patterson et al., 1991; Sopher et al., 1993; Lovell et al., 1994; Guadalupi et al., 1996; Uchino et al., 2003). The mutation associated with $\beta$-mannosidosis at the genetic level has also been discussed (Lovell et al., 1994; Alkhyat et al., 1998; Uchino et al., 2003).
A

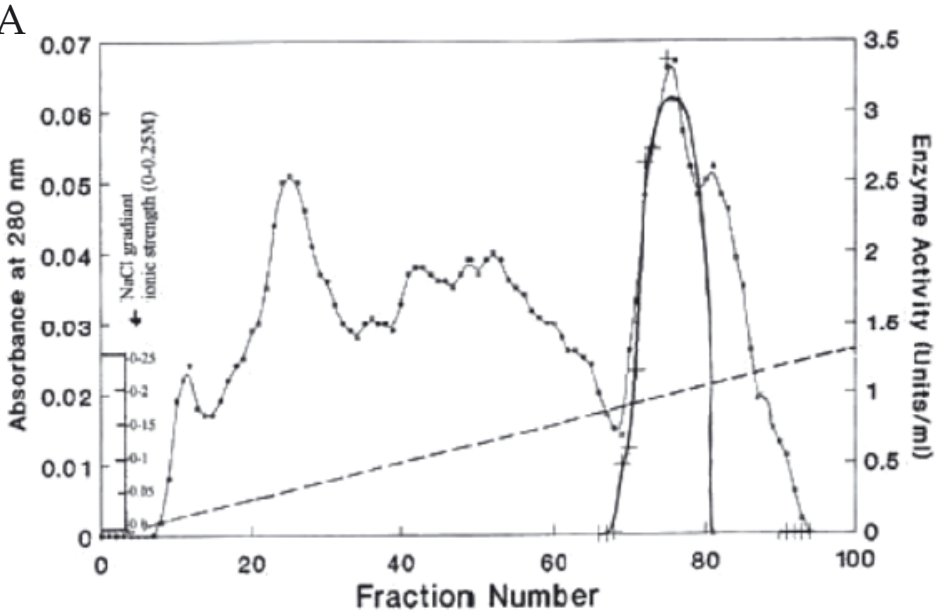

B

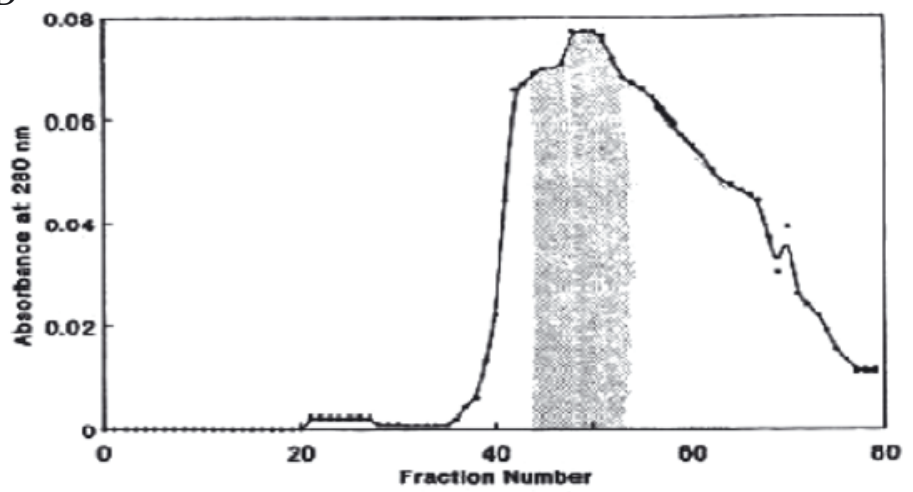

Figure 5. A chromatographic profile of purification of $\beta$-mannosidase on DEAE-cellulose and size exclusion chromatography. (A) The dialysed protein extract was adsorbed on DEAE-cellulose ion exchanger $(1.5 \mathrm{~cm} \times 20 \mathrm{~cm})$ and eluted with linear salt gradient of $\mathrm{NaCl}(0$ to $0.25 \mathrm{M}$ ) in acetate buffer. $\beta$-Mannosidase activity was assayed from eluted peak fractions across the gradient $(\bullet)$. The peak fractions which showed the enzyme activity (+) were collected and concentrated. The enzyme was eluted at $0.15 \mathrm{M}$ to $0.16 \mathrm{M} \mathrm{NaCl}$ salt concentration. (B) The concentrated fractions from DEAEcellulose were loaded on Sephadex-G 200 equilibrated with mannosidase buffer and then eluted with same buffer. The peak fractions which showed the $\beta$-mannosidase activity (shadow area) were collected and confirmed by ELISA and enzyme assay. 

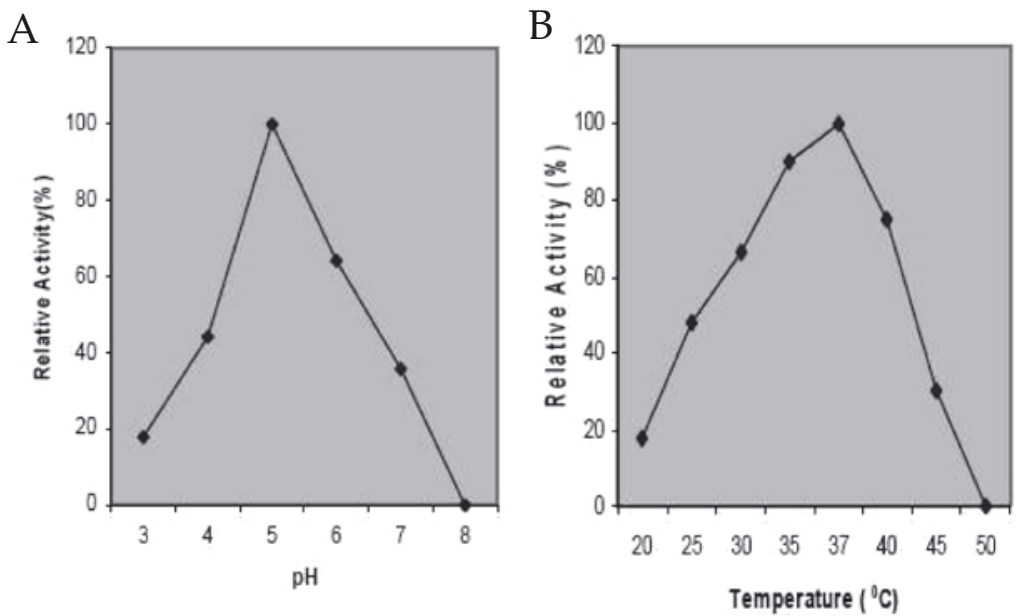

Figure 6. Effect of $\mathrm{pH}$ and temperature on recombinant human $\beta$-mannosidase enzymes (MAN22 and MAN28).

Hydrolysis of $p$-nitrophenyl- $\beta$-Dmannopyranoside was measured at $37^{\circ} \mathrm{C}$ for $3 \mathrm{~h}$ in a $\mathrm{pH}$ range between 3 and 9. The effect of temperature on enzyme activity was also measured at $\mathrm{pH} 5.0$ at temperature range between 20 and $50^{\circ} \mathrm{C}$. The enzymes were highly active at $\mathrm{pH} 5.0$ and at $37^{\circ} \mathrm{C}$.

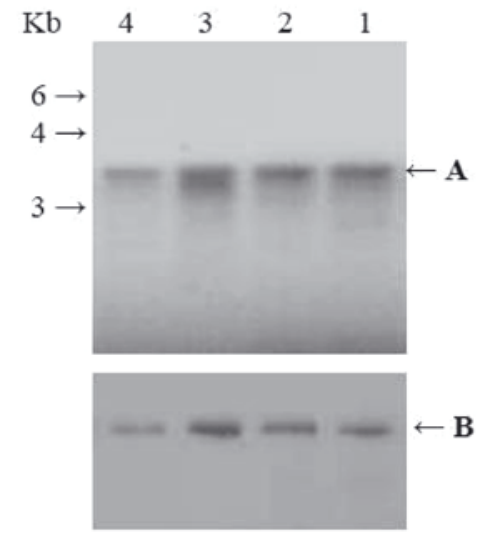

Figure 7. Northern blot analysis of $\beta$-mannosidase RNA of normal human tissues.

(A) Poly $\left(\mathrm{A}^{+}\right)$RNA of $\beta$-mannosidase $(2 \mu \mathrm{g})$ was hybridized with non-radioactive biotin labeled full length RTPCR DNA of human $\beta$-mannosidase gene and visualized with streptavidin-alkaline phosphatase and NBT/BCIP substrate; (lane 1), B-cells, (lane 2), T-cells, (lane 3), placenta and (lane 4), leukocytes. The locations of standard size marker are indicated on the left side of the figure. Arrow (right side) indicates the significant signals corresponding to human $3.7 \mathrm{~kb}$ RNA transcript. (B) The blot was rehybridized with human $\beta$-actin DNA probe as an internal control after removal of MANB probes.
The full length open reading frame (ORF) of human placental $\beta$-mannosidase gene was synthesized from a cDNA clone by PCR using forward and reverse primers which were designed from the sequence of reported human $\beta$-mannosidase gene (Alkhyat et al., 1998). The sequence homology of the cloned $\beta$-mannosidase gene is $99 \%$ with the reported human $\beta$-mannosidase cDNA sequence (Alkhyat et al., 1998). The 16 nucleotide differences were observed in the open reading frame of the transcript. Due to variations in nucleotides, sixteen triplet codons were also changed. Seven triplet codons coded the same amino acids whereas nine of them coded different amino acids. The start codon (ATG) in the ORF sequence of the $\beta$-mannosidase is similar to the eukaryotic translation initiation codon (Kozak, 1984). The sequence of amino acids in the MANB showing features of signal peptide sequence is followed by the ATG start codon and is in agreement with studies already reported (Von-heijne, 1986). The upstream sequence is similar to the Kozak sequence (CC(AorG) CCATGG) (Kozak, 1984) which is reportedly conserved in bovine and caprine but less conserved in humans (Beccari et al., 2001). Alkhyat et al. (1997) reported that the $\beta$-mannosidosis is human

Table 3. Effect of various reagents on recombinant human MAN22 and MAN28 enzyme activity.

Purified enzymes were preincubated with compounds separately for $15 \mathrm{~min}$ at $37^{\circ} \mathrm{C}$ and the enzyme activity was determined under standard assay conditions. The compounds were dissolved in $0.1 \mathrm{M}$ acetate buffer $\mathrm{pH}$ 5.0.

\begin{tabular}{lclc}
\hline $\begin{array}{l}\text { Metal ions } \\
(1.5 \mathrm{mM})\end{array}$ & $\begin{array}{c}\text { Residual } \\
\text { activity }(\%)\end{array}$ & $\begin{array}{l}\text { Organic compounds } \\
(5 \mathrm{mM})\end{array}$ & $\begin{array}{c}\text { Residual } \\
\text { activity }(\%)\end{array}$ \\
\hline Control & 100 & PMSF & 100 \\
$\mathrm{Mg}^{2+}$ & 100 & Triton-X100 & 100 \\
$\mathrm{Mn}^{2+}$ & 100 & Iodoacetate & 0 \\
$\mathrm{Ca}^{2+}$ & 100 & SDS & 0 \\
$\mathrm{Fe}^{3+}$ & 100 & DMF & 0 \\
$\mathrm{Co}^{2+}$ & 80 & DMSO & 0 \\
$\mathrm{~Pb}^{2+}$ & 78 & Ethanol & 0 \\
$\mathrm{Zn}^{2+}$ & 0 & & \\
$\mathrm{Cd}^{2+}$ & 0 & & \\
$\mathrm{Cu}^{2+}$ & 0 & & \\
$\mathrm{Ag}^{+1}$ & 0 & & \\
\hline
\end{tabular}


genetic disease which is associated with the splice site mutation $(A \rightarrow G)$ at position -2 of the $3^{\prime}$ splice acceptor site. The deletion of $172 \mathrm{bp}$ in the defective gene as compared to normal human MANB gene results in frame shifting or exon skipping and early addition of a stop codon that truncates the translation. Uchino et al. (2003) reported the insertion of ATAA between exon 7 and 8 which results in the transition of $\mathrm{G} \rightarrow \mathrm{A}$ at the donor site of intron 7 . The activation of cryptic splice site results in frame shifting and termination of translation. The null mutation in one heterozygous patients reported by Bedilu et al. (2002) gives evidence of nonsense mutation in exon 2 and in exon 10 which results in truncation, whereas the study in a homozygous patient indicates a deletion mutation in exon 11 which leads to truncation of the gene. The comparison of our MANB gene sequence with other reported MANB gene sequences given by Alkhyat et al. (1997), Uchino et al. (2003) and Bedilu et al. (2002) does not indicate any splice mutation or deletion of nucleotides which may affect MANB enzyme activity.

A $75 \%$ amino-acid homology was found with the amino-acid sequence of goat, mouse and bovine $\beta$-mannosidase which indicated the evolutionary conservation of this protein. The amino-acid sequence of $\beta$-mannosidase revealed eight glycosylation sites in human $\beta$-mannosidase gene which is in agreement with already reported sites (Alkhyat et al., 1998), whereas ten, six and four glycosylation sites are reported in mouse (Beccari et al., 2001), bovine (Chen et al., 1995) and goat $\beta$-mannosidase gene (Leipprandt et al., 1996) respectively. The amino-acid residues at position 35 and 77 of the deduced amino-acid sequence of $\beta$-mannosidases share similar glycosylation sites as reported in previous human $\beta$-mannosidase but amino-acid residue at position 297 is different (Alkhyat et al., 1998). Isoleucine is observed at position 235 of amino-acid sequence of this enzyme whereas Alkhyat et al. (1998) reported valine/isoleucine at position 235 which is also in agreement with our observation.

In order to carry out the expression studies, the $\beta$-mannosidase gene was subcloned in pET vectors $(\mathrm{pET} 22 \mathrm{~b}(+)$ and pET28a $(+))$. A glycine residue (ggg) was inserted after the initiation codon (ATG) to create the $\mathrm{NcoI}$ site at $\mathrm{N}$-terminal region of the $\beta$-mannosidase gene. The addition of glycine residue after the start codon did not affect on the translation process and enzyme activity. The recombinant MAN22 and MAN28 enzyme was purified to homogeneity by ion exchange and gel permeation chromatography. The overexpression of $\beta$-mannosidase enzyme was observed with 1 $\mathrm{mM}$ IPTG for $12 \mathrm{~h}$ at $37^{\circ} \mathrm{C}$ in clone SA22 and SA28 and the specific activity varies from $10 \mathrm{U} / \mathrm{mg}$ to $13 \mathrm{U} /$ $\mathrm{mg}$, respectively. The specific activity of MAN28 is higher than MAN22 but the total protein concentration is high in MAN22. The purified protein was further characterized by SDS/PAGE and Western blot as- say which revealed a single $97 \mathrm{kDa}$ protein band. The percentage recovery is nearly same but the specific activity is high in MAN28 protein. Both recombinant enzymes have the same $\mathrm{pH}$ and temperature optima. Both enzymes showed activity with $p$-nitrophenyl- $\beta$ D-mannopyranoside while no activity was observed with $p$-nitrophenyl- $\alpha$-D-mannopyranoside. The inhibition of enzyme activity by $\mathrm{Zn}^{2+}, \mathrm{Co}^{2+}, \mathrm{Cu}^{2+}, \mathrm{Pb}^{2+}, \mathrm{Ag}^{1+}$ indicates that sulfhydryl or carboxylic group may be involved in enzyme activity.

The expression of MANB was not achieved in E. coli strain BL21(DE3) whereas it was obtained in E. coli strain BL21-codon plus which is useful for expression of eukaryotic genes with high GC content. The efficient heterologous expression in E. coli strain BL21-codon plus may be due to insertion of extra copies of rare genes for tRNA which are not routinely used in expression.

The comparison of $\beta$-mannosidase expression in human leukocytes, B and T cell and placenta was analyzed by Northern hybridization. The transcript size remains the same $3.7 \mathrm{~kb}$ in all tissues which is in agreement with other studies (Alkhyat et al., 1998). The moderate level of expression in placental tissue may be due to high metabolic flux. The identification of molecular defect in patients with human $\beta$-mannosidosis, has been hindered by the lack of information about the human $\beta$-mannosidase gene. In this study, the $\beta$-mannosidase gene was cloned and expressed. Recombinant $\beta$-mannosidase enzyme has been purified to homogeneity and characterized. This will help to identify the structure, function and catalytic activity of this enzyme. The comparative studies of $\beta$-mannosidases of different species are underway.

\section{REFERENCES}

Alkhayat AH, Kraemer SA, Leipprandt JR, Macek M, Kleijer WJ, Friderici KH (1998) Human $\beta$-mannosidase cDNA characterization and first identification of a mutation associated with human $\beta$-mannosidosis. Hum Mol Genet 7: 75-83.

Ademark P, Lundqvist J, Hagglund P, Tenkanen M, Torto N, Tjerneld F, Stalbrand H (1999) Hydrolytic properties of a $\beta$-mannosidase purified from Aspergillus niger. J Biotechnol 8: 281-289.

Abbitt B, Jones MZ, Kasari TR, Storts RW, Templeton JW, Holland PS, Castenson PE (1991) B-mannosidosis in twelve Salers calves. J Am Vet Med Assoc 198: 109-113.

Ausubel FM, Brent R, Kingston RE, More DD, Seidman JG, Smith JA, Struhl K (2002) Short protocols in molecular biology, 1st edn. John Wiley \& Sons Inc, Canada.

Bauer MW, Bylina EJ, Swanson RV, Kelly RM (1996) Comparison of a $\beta$-glucosidase and a $\beta$-mannosidase from the hyperthermophilic archaeon Pyrococcus furiosus. $\mathrm{Pu}-$ rification, characterization, gene cloning, and sequence analysis. J Biol Chem 271: 23749-23755.

Beccari T, Bibi L, Stinchi S, Stirling JL, Orlacchio A (2001) Mouse $\beta$-mannosidase: cDNA cloning, expression, and chromosomal localization. Biosci Rep 21: 315-323. 
Bedilu R, Nummy KA, Cooper A, Wevers R, Smeitink J, Kleijer WJ, Friderici KH (2002) Variable clinical presentation of lysosomal $\beta$-mannosidosis in patients with null mutations. Mol Genet Metab 77: 282-290.

Bradford MM (1976) A dye binding assay for protein. Ann Biochem 72: 248-254.

Bryan L, Schmutz S, Hodges SD, Snyder FF (1990) Bovine $\beta$-mannosidase deficiency. Biochem Biophys Res Commun 173: 491-495.

Chen H, Leipprandt JR, Traviss CE, Sopher BL, Jones MZ, Cavanagh KT, Friderici KH (1995) Molecular cloning and characterization of bovine $\beta$-mannosidase. J Biol Chem 270: 3841-3848.

Cooper A, Hatton C, Thornley M, Sardharwalla IB (1988) Human $\beta$-mannosidase deficiency: biochemical findings in plasma, fibroblasts, white cells and urine. J Inherit Metab Dis 11: 17-29.

Cooper A, Wraith JE, Savage WJ, Thornley M, Noronha MJ (1991) $\beta$-Mannosidase deficiency in a female infant with epileptic encephalopathy. J Inherit Metab Dis 14: $18-22$.

Duffaud GD, McCutchen CM, Leduc P, Parker KN, Kelly RM (1997) Purification and characterization of extremely thermostable $\beta$-mannanase, $\beta$-mannosidase, and alpha-galactosidase from the hyperthermophilic eubacterium Thermotoga neapolitana 5068. Appl Environ Microbiol 63: 169-177.

Gort L, Duque J, Fabeiro JM, Zulaica A, Coll MJ, Chabas A (2006) Molecular analysis in two $\beta$-mannosidosis patients: description of a new adult case. Mol Genet Metab 89: 398-400.

Guadalupi R, Bernard M, Orlacchio A, Foglietti MJ, Emiliani C (1996) Purification and properties of human urinary $\beta$-D-mannosidase. Biochim Biophys Acta 1293: 9-16.

Harlow ED, Lane D (1988) Antibodies, A laboratory manual. Cold Spring Harbour Labs., USA.

Johnstone A, Thrope R (1982) Immunochemistry in practice. 2nd edn. Blackwell Scientific Publication, UK.

Jolly RD, Thompson KG, Bayliss SL, Vidler BM, Orr MB, Healy PJ (1990) $\beta$-Mannosidosis in a Salers calf: a new storage disease of cattle. N Z Vet J 38: 102-105.

Jones MZ, Cunningham JG, Dade AW, Alessi DM, Mostosky UV, Vorro JR, Benitez JT, Lovell KL (1983) Caprine $\beta$-mannosidosis: clinical and pathological features. J Neuropathol Exp Neuro 42: 268-285.

Jones MZ, Rathke EJ, Gage DA, Costello CE, Murakami K, Ohta M, Matsuura F (1992) Oligosaccharides accumulated in the bovine $\beta$-mannosidosis kidney. J Inherit Metab Dis 15: 57-67.

Kleijer WJ, Hu P, Thoomes R, Boer M, Huijmans JG, Blom W, Van Diggelen OP, Seemanova E, Macek M (1990) B-mannosidase deficiency: heterogeneous manifestation in the first female patient and her brother. J Inherit Metab Dis 13: 867-872.

Kozak M (1984) Compilation and analysis of sequence upstream from the translation start site in eukaryotic mRNA. Nucleic Acid Res 12: 857-872.

Kurakake M, Komaki T (2001) Production of $\beta$-mannanase and $\beta$-mannosidase from Aspergillus awamori K4 and their properties. Curr Microbiol 42: 377-380.

Laemmli UK (1970) Cleavage of structural proteins during the assembly of the head of bacteriophage T4. Nature 227: 680-685.

Leipprandt JR, Kraemer SA, Haithcock BE, Chen H, Dyme JL, Cavanagh KT, Friderici KH, Jones MZ (1996) Caprine $\beta$-mannosidase: sequencing and characterization of the cDNA and identification of the molecular defect of caprine $\beta$-mannosidosis. Genomics 37: 51-56.
Levade T, Graber D, Flurin V, Delisle MB, Pieraggi MT, Testut MF, Carriere JP, Salvayre R (1994) Human $\beta$ mannosidase deficiency associated with peripheral neuropathy. Ann Neurol 35: 116-119.

Lovell KL, Kranich RJ, Cavanagh KT (1994) Biochemical and histochemical analysis of lysosomal enzyme activities in caprine $\beta$-mannosidosis. Mol Chem Neuropathol 21: $61-74$.

Mo B, Bewley JD (2002) B-mannosidase activity during and following germination of tomato (Lycopersicon esculentum Mill.) seeds. Purification, cloning and characterization. Planta 215: 141-152.

Patterson JS, Jones MZ, Lovell KL, Abbitt B (1991) Neuropathology of bovine $\beta$-mannosidosis. J Neuropathol Exp Neurol 50: 538-546.

Pearce RD, Callahan JW, Novak A, Little PB, Clarke JT (1990) Properties of partially purified goat kidney $\beta$-Dmannosidase. Br Vet J 146: 270-280.

Percheron F, Foglietti MJ, Bernard M, Ricard B (1992) Mammalian $\beta$-D-mannosidase and $\beta$-mannosidosis. Biochimie 74: 5-11.

Poenaru L, Akli S, Rocchiccioli F, Eydoux P, Zamet P (1992) Human $\beta$-mannosidosis: a 3-year-old boy with speech impairment and emotional instability. Clin Genet 41: 331-334.

Plummer DT (1987) An introduction to practical biochemistry. 3rd edn, McGraw Hill, UK.

Render JA, Lovell KL, Jones MZ (1988) Otic pathology of caprine $\beta$-mannosidosis. Vet Pathol 25: 437-442.

Rodriguez-Serna M, Botella-Estrada R, Chabas A, Col MJ, Oliver V, Febrer MI, Aliaga A (1996) Angiokeratoma corporis diffusum associated with $\beta$-mannosidase deficiency. Arch Dermatol 132: 1219-1222.

Sambrook J, Russel DW (2001) Molecular cloning, A laboratory manual. 3rd edn. Cold Spring Harbour Labs, USA.

Samra ZQ, Athar MA (2008) Production and immunocomparative study of human lysosomal $\beta$-mannosidase antibodies. Pak J Zool 40: 185-192.

Sedel F, Friderici K, Nummy K, Caillaud C, Chabli A, Durr A, Lubetzki C, Agid Y (2006) Atypical Gilles de la Tourette syndrome with $\beta$-mannosidase deficiency. Arch Neuro 63: 129-131.

Sopher BL, Traviss CE, Cavanagh KT, Jones MZ, Friderici KH (1993) Bovine kidney $\beta$-mannosidase: purification and characterization. Biochem J 5: 343-347.

Thiel T, Bissen S, Lyons EM (2002) Biotechnology, DNA to Protein, 1st edn, McGraw Hill companies, Inc, NY, USA.

Towbin HK, Staehelin T, Gordon J (1979) Electrophoretic transfer of proteins from polyacrylamide gels to nitrocellulose membrane. Proc Natl Acad Sci USA 76: 43504359 .

Uchino Y, Fukushige T, Yotsumoto S, Hashiguchi T, Taguchi H, Suzuki N, Konohana I, Kanzak T (2003) Morphological and biochemical studies of human $\beta$ mannosidosis: identification of a novel $\beta$-mannosidase gene mutation. Br J Dermatol 149: 23-29.

Van PJ, Dorland L, Duran M, Hokke CH, Kamerling JP, Vliegenthart JF (1990) Sialyl-alpha 2-6-mannosyl- $\beta$ 1-4$N$-acetylglucosamine, a novel compound occurring in urine of patients with $\beta$-mannosidosis. J Biol Chem 5: 19685-19689.

Von-heijne G (1986) A new method for predicting signal sequence cleavage site. Nucleic Acids Res 14: 4683-4690.

Wysocki LJ, Sato VL (1978) Panning for lymphocytes: A method for cell selection. Proc Natl Acad Sci USA 75: 2844-2848. 